\title{
Cooperative Learning Mode of Students Team Achievement Division (STAD) with Mind Mapping Technique to Increase 4th Grade Students Learning Result
}

\author{
Cumalasari Erita Indah, Made Pidarta, Ketut Prasetya \\ Universitas Negeri Surabaya \\ Surabaya, Indonesia \\ cumala.eri@gmail.com
}

\begin{abstract}
This study objective was to (1) Develop the implementation of cooperative learning (2) Develop Students Team Achievement Division (STAD) learning model (3) Develop Mind Mapping technique (4) Improve student learning result. This research uses a qualitative positivistic approach with Classroom Action Research type. The research design includes a $n$ initial study to look at the early conditions before the researcher undertakes the research and development of two cycles with the planning, implementation and observation, reflection and revision phase of each cycle. Subjects used in the study amounted to $\mathbf{4 0}$ students. The results of this study was the development of cooperative learning type Students Team Achievement Division (STAD) with mind mapping techniques that can improve affective aspects, psychomotor aspects, and cognitive aspects of students. This was indicated by the affective score of the students in the initial study received a score of 25,5 on enough categories and score 4,3 on the cycle II on very good category. The psychomotor aspect obtained scored 2,2 on enough category in the initial study and get score of 4,4 in the second cycle on very good category. The initial cognitive scores of the study scored 60,5 under the minimum completeness criterion (KKM) and 80,5 in the second cycle exceeded the KKM.
\end{abstract}

Keywords: cooperative learning, mind mapping, (STAD)

\section{INTRODUCTION}

Education is a conscious effort to prepare learners through counseling, teaching and or training activities for their future role [1] Based on the mentioned educational objectives, it can be seen that basic education is very important for human development because it will determine the success of someone in the next level. Given the importance of basic education, there is a need for development or innovation in education that includes models, strategies, approaches and learning techniques that are accompanied by innovative and creative media to achieve the educational goals. The problems encountered is the incompatibility of the use of learning methods, learning strategies and learning techniques with the state of their students.

One of the goals of education is to educate students to understand human diversity, and to have common and interdependent relationships among all people, to achieve common goals. "Cooperative learning" is an important way to train students' ability to live with others [2] Cooperative learning strategies stimulate cognitive activity and promote higher levels of attainment [3]

The evaluation of cooperative learning involves student self-learning, cooperative discussion and communication. It takes into account student learning situations in each phrase with more stress to approaches, thoughts, experiences, and interpersonal relationships of students and to perform formative evaluations [4] In the cooperative learning model the teacher provides links for students to discover more meaning in lessons they are learning. Over time, students increase their creativity and learning efficiency [5]

There are five indicators of cooperative learning by Johnson \& Johnson [6]: (a) positive interdependence (b) interaction between students (c) individual responsibility (d) interpersonal skills (e) group process. Effective cooperative learning can generate students' potential for sleep, enabling sealed memory and opening claustrophobic thoughts. The group works together to learn from passivity to initiative, selfstudy, group communication, whole class discussion, teacher suggestions and other organic integration. [7] Cooperative learning model type STAD (Student Team Achievement Division) is better used in the learning process because this learning model is effective in improving learning result [8] STAD is more effective for improving student learning outcomes [9]This cooperative learning can make students more enthusiastic and responsible in learning and to help students absorb learning materials better [10]

Learning model type Student Teams Achievement Division (STAD). Learning model will be more effective if students are also given the opportunity to contribute directly and develop creativity in pouring ideas, such as the use of mind mapping techniques in learning.

Mind mapping technique is a mapping of information stored in the mind of the reading process. Mind mapping learning model has advantages in influencing students learning result [11]This technique can be an excellent alternative to applied in learning because it can help a person understand 
concepts and memorize information with a learning tool by utilizing his own creativity.

The mind mapping method has proved effective as an alternative to solving low-thinking problems and student [12]Achieving students' creative thinking skills better when using mind mapping, better than conventional means [13]To determine the progress achieved then there must be a criterion (benchmark) that refers to the objectives that have been determined so that it can be known how much influence of teaching and learning strategies to the success of student learning. Learning result include cognitive, affective, and psychomotor abilities. Based on the research focus that has been discussed, the purpose of this research was to (1) Develop the implementation of cooperative learning (2) Develop Students Team Achievement Division (STAD) learning model (3) Develop Mind Mapping technique (4) Improve student learning result. Thus, this study aims to describe how the model of cooperative learning model type Students Team Achievement Division (STAD) with Mind Mapping techniques can improve student learning result.

\section{METHOD}

This research uses qualitative positivistic approach with Classroom Action Research type. The study design includes an initial study to look at the initial conditions. Initial study begins with a test of the ability to answer the problem that serves as a preliminary information to know the ability of students in cognitive aspects. After completing the cognitive tests, the researchers conducted interviews with several classroom students to find out the difficulties and problems during the learning process. The next step, researchers carry out the development of two cycles with the planning, implementation and observation, reflection and revision in each cycle. Here is the development phase cycle used in this study:

The Stages of Development

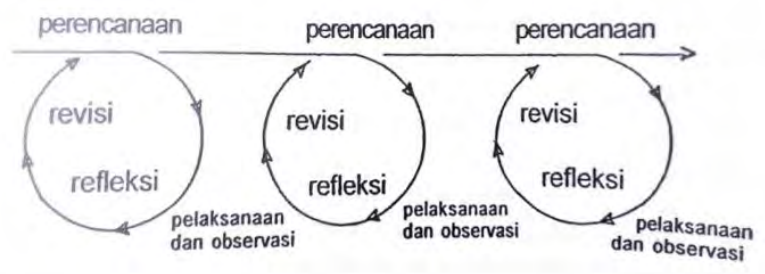

(Source: Pidarta, 2008)

Subjects in this study amounted to 40 students who are fourth graders in one elementary school in Surabaya. This research was integrated with Social study subjects. The selection of subjects was based on the fourth grade of education which is a transition from low to high class, so that the fourth grade students need more varied attention and learning model in order to facilitate students in understanding the material given by the teacher.

\section{RESULT AND DISCUSSIONS}

There are four results in this study, here is a matrix of research results in this study:

\section{A. Focus 1 Results Cooperative learning}

TABLE I. RESULTS OF FOCUS 1

\begin{tabular}{|c|c|c|}
\hline \multirow{2}{*}{$\begin{array}{c}\text { Early Study } \\
\text { Results }\end{array}$} & \multicolumn{2}{|c|}{ Development Result } \\
\hline & Cycle I & Cycle II \\
\hline $\begin{array}{l}\text { Positive } \\
\text { interdependence is } \\
\text { lacking, interaction } \\
\text { between students is } \\
\text { sufficient, } \\
\text { individual } \\
\text { responsibility is } \\
\text { sufficient, } \\
\text { interpersonal skill } \\
\text { enough, and group } \\
\text { process enough }\end{array}$ & $\begin{array}{l}\text { Mutual dependence that } \\
\text { is positive enough, } \\
\text { enough social } \\
\text { interaction, individual } \\
\text { responsibility enough, } \\
\text { sufficient interpersonal } \\
\text { skills and group } \\
\text { processes are also } \\
\text { sufficient. }\end{array}$ & $\begin{array}{l}\text { Positive } \\
\text { interdependence is } \\
\text { lacking, interaction } \\
\text { between students is } \\
\text { sufficient, individual } \\
\text { responsibility is } \\
\text { sufficient, interpersonal } \\
\text { skill enough, and group } \\
\text { process enough }\end{array}$ \\
\hline
\end{tabular}

On research results focus 1 researchers use five indicators as a determinant of cooperative learning success, namely:

1. Interdependence

2. Interaction between students

3. Individual responsibility

4. Interpersonal skills

5. Group process

The result of the initial study on this research was found that the score of each of the five indicators in the poor category with score 1,$8 ; 3 ; 2,6 ; 2,3 ; 2,5$. In the development of cooperative learning in cycle I the five indicators have increased but, the mean score on these five indicators is 2,84 still in enough category. Based on the results of cycle I, researchers continue the development of cooperative learning in cycle II.

The results of cycle II in this study indicate that the mean score on the five indicators are in very good category with score 4,32. Based on the results of the research in cycle II which indicates an increase and already in the expected category, the researcher decided to stop the research in cycle I and not continue the development of cooperative learning in cycle III.

\section{B. Results Focus 2 Learning Model Type STAD (Students Team Achievement Division)}

TABLE II. FOCUS RESULTS 2

\begin{tabular}{|c|c|c|}
\hline \multirow{2}{*}{$\begin{array}{l}\text { Early Study } \\
\text { Results }\end{array}$} & \multicolumn{2}{|c|}{ Development Result } \\
\hline & Cycle I & Cycle II \\
\hline $\begin{array}{l}\text { Good class } \\
\text { presentation, less } \\
\text { teacher quiz, and } \\
\text { recalling enough }\end{array}$ & $\begin{array}{l}\text { Class presentations are } \\
\text { in very good category, } \\
\text { teacher quiz score score } \\
\text { and recall is categorized } \\
\text { enough. }\end{array}$ & $\begin{array}{l}\text { Quizzes from teachers } \\
\text { are very good and } \\
\text { recall also very good }\end{array}$ \\
\hline
\end{tabular}

On the research results focus 2 researchers using three indicators as a determinant of the successful development of learning model Type Students Team Achievement Division 
(STAD), namely:
1. Class presentation
2. Quiz from teacher
3. Recalling

The result of the preliminary study on this research study found that the score of the three indicators are respectively are 3,$7 ; 2 ; 2,5$ in the categories of good, poor and enough. In the development of learning model Type Students Team Achievement Division (STAD) in the third cycle I have improved indicators are classified into the category is very good with score 4,4; teacher quiz indicators and recall in enough categories with score 2,7 and 3. Based on the results of cycle I, the researcher continues the development of learning model Type Students Team Achievement Division (STAD) in cycle II.

Cycle II focuses on teacher quiz indicator and recall because on these two indicators in cycle I are still in enough category, so follow-up needed in cycle II to improve both of these indicators. The results of cycle II of these two indicators have improved yields into very good categories with score 4,2 and 4,6 .

Based on the results of the research in cycle II which ndicates an increase and already in the expected category, the researcher decided to stop the research in cycle I and not continue the development of cooperative learning in cycle III.

\section{Focus Result III Mind Mapping Technique}

TABLE III. FOCUS RESULT 3

\begin{tabular}{|c|c|c|}
\hline \multirow{2}{*}{$\begin{array}{l}\text { Early Study } \\
\text { Results }\end{array}$} & \multicolumn{2}{|c|}{ Development } \\
\hline & Cycle I & CyCle II \\
\hline $\begin{array}{l}\text { Selection of good } \\
\text { topics, lack of } \\
\text { concept } \\
\text { concordance, } \\
\text { sorting less } \\
\text { concepts, } \\
\text { drafting is and } \\
\text { lack }\end{array}$ & $\begin{array}{l}\text { The selection of topics } \\
\text { is very good, } \\
\text { conformity of concept is } \\
\text { sufficient, sorting } \\
\text { enough concepts, and } \\
\text { drafting is also quite } \\
\text { enough }\end{array}$ & $\begin{array}{l}\text { Selection of good } \\
\text { topics, lack of concept } \\
\text { concordance, sorting } \\
\text { less concepts, and } \\
\text { drafting is also lack }\end{array}$ \\
\hline
\end{tabular}

In the research results focus 3 researchers using four indicators as a determinant of the successful development of Mind Mapping Technique, namely:

1. Selection of topics

2. Conformity of concept

3. Sorting concept

4. Drafting concept

The result of the initial study in this research study found the score of the four indicators of concept selection in the enough category with score 3 and other indicators in the poor category with score $2 ; 2$; and 2 . Based on the results of preliminary studies, researchers conducted the development of mind mapping techniques on cycle I.

The results of cycle I show an increase but not significant, this was seen from there is only one indicator (selection of topics) very good category with score 4,3 ; and the other three indicators are still in the score with enough category with score 2,$5 ; 2,7 ; 2,8$. Based on the results of cycle I, researchers continue to develop mind mapping techniques in cycle II by focusing on three indicators which is still in enough category.

The development of mind mapping technique in cycle II got the result that the four indicators showed the increase that can be seen from the value of each indicator is in very good category with score 4,$3 ; 4,3 ; 4,6 ; 4,4$. Based on the results in cycle II, the researcher discontinued the development of mind mapping technique and did not continue in cycle III because already get satisfactory result in cycle II.

\section{Results Focus IV Learning Outcomes}

TABLE IV. FOCUS RESULT 4

\begin{tabular}{|c|c|c|}
\hline \multirow{2}{*}{$\begin{array}{l}\text { Early Study } \\
\text { Result }\end{array}$} & \multicolumn{2}{|c|}{ Development } \\
\hline & Cycle I & Cycle II \\
\hline $\begin{array}{l}\text { Cognitive Aspects } \\
\text { whose average } \\
\text { score is still far } \\
\text { below the KKM, } \\
\text { affective aspect } \\
\text { scores included in } \\
\text { the category of } \\
\text { less, and also the } \\
\text { psychomotor } \\
\text { aspect score } \\
\text { included in the } \\
\text { category of less }\end{array}$ & $\begin{array}{l}\text { Cognitive aspect is still } \\
\text { under KKM, score } \\
\text { indicator good affective } \\
\text { aspects, and good } \\
\text { psychomotor aspect } \\
\text { scores }\end{array}$ & $\begin{array}{l}\text { Cognitive aspects } \\
\text { have exceeded the } \\
\text { specified KKM, } \\
\text { excellent affective } \\
\text { aspect scores, and } \\
\text { excellent } \\
\text { psychomotor aspect } \\
\text { scores }\end{array}$ \\
\hline
\end{tabular}

In the research results focus 4 researchers using three aspects as a determinant of the success of development of learning outcomes, namely:

1. Cognitive aspects

2. Affective aspects

3. Psychomotor aspect

The result of the initial study in this study was found to be the score of the three aspects with categories far below the minimum thres hold value for the cognitive, the lack affective, and the less psychomotor aspects with score 60,$5 ; 25,5 ; 2,2$. Based on the results of preliminary studies, researchers do the development of learning outcomes in cycle I.

The results of Cycle I show an increase but not significant this is seen from the cognitive aspect to get a score that is still below the KKM with score 69,5; affective aspect and psychomotor values with score 3,1 and 3,08 both in enought categories.

The results in cycle I is required to be less satisfactory so that the researcher used as a reflection to develop the learning outcomes in cycle II. Researchers continue the development of learning outcomes in cycle II to maximize student learning result.

The result of learning result development in cycle II shows that there has been an improvement in the students' learning result which are indicated by the value on the cognitive aspect already above the minimum completeness criterion (KKM) with mean score 80,5; the affective aspect score in the 
category is very good with score 4,36; and the value on the aspect of the psychomotor in very good category with score 4,4. Based on the results in cycle II, the researcher discontinued the development of mind mapping technique and did not continue on cycle III because already get satisfactory results in cycle II

From the results of research and observations made in the initial study, it was known that these five indicators have not been achieved. After conducted the research and observation in cycle I, it found that the score of five indicators experienced improvement but not so significant and still included in the category enough.

Research and observation finally continued in cycle II. From cycle II it was known that the five indicators of cooperative learning model have been achieved well with excellent category average score. this is in line with the results of research $\mathrm{Fu}$ [5] which states that this method can fully mobilize students to participate in learning, thus promoting learning itself, which can effectively improve the ability of independent learning and students' thinking skills. Cooperative learning can greatly improve the efficiency of classroom teaching.

At the same time, students learn from one another, who bring mutual assistance. $\mathrm{Fu}$ [5] in line with the results of this study, previous research also shows that the application of cooperative learning models in the context of mathematics classes can improve good social skills in teamwork and motivation to solve math problems [14]

Student Team Achieve cooperative model can help student more enthusiast and responsible in learning for help studnt absorb learning matter better. The result of this research is supported by the research of Husamah and Pantiwati (2014) which shows that the Student Team Achievement Division (STAD) learning model can improve the students' ability to master the learning materials.

Furthermore, this research is also supported by Ling's (2016) research result which shows that the Student Team Achievement Division (STAD) learning model can be used to improve student's learning achievement. The implementation module as a combined teaching material of STAD cooperative learning has a significant effect on science process skills and with student achievement (Prihatnawati, et. al., 2017).

Research that is in line with the results of this study was a study conducted by Wilson and Yunus (2016) which shows that mind mapping techniques have a positive impact in improving learning result. Furthermore, this research is also supported by Ling's (2016) research result which shows that the Student Team Achievement Division (STAD) learning model can be used to improve student's learning achievement.

The Application of cooperative learning model type STAD with image media can improve learning result and motivation to learn social study (Handayani, et. al., 2017). Similar results were also obtained from a study (Parmiti \& Margunayasa, 2017) which showed that students' science learning result become higher with mind maps of the student group that learning with conventional learning. The mind mapping method proved to be effective as an alternative to solving problems of low thinking and student competence (Putra, et. al., 2017) achieving students' creative thinking skills better when using mind mapping, better than conventional means.

\section{REFERENCES}

[1] S. Amri, "Pengembangan dan model pembelajaran dalam kurikulum 2013," Jakarta: Prestasi Pustaka, 2013.

[2] X. Wang, "Discussion on Application of Multimedia Teaching in College English Vocabulary Teaching," Open J. Mod. Linguist., vol. 6, no. 03, p. 177, 2016.

[3] E. Pasaribu, M., \& Sianturi, "Effects of Cooperative Learning Strategy and Reasoning on Students Learning Outcomes in Physics.," First Indones. Commun. Forum Teach. Train. Educ. Fac. Leaders Int. Conf. Educ. 2017 (ICEI 2017), 2018.

[4] L. and R. D. Gong, The Application of Cooperative Learning in English Study. Atlantis Press, 2016.

[5] R. Fu, "Teaching Microbiology," Int. Conf. Educ. Manag. Sci. Econ., 2016.

[6] M. P. Trianto and M. Pd, "Mendesain model pembelajaran inovatifprogresif," Jakarta: Kencana, 2009.

[7] M. Xueyan, C., \& Beibei, "Research on the Application of Group Cooperative Learning Model in the Teaching of Internal Medicine Nursing," Int. Conf. Econ. Dev. Educ. Manag. (ICEDEM 2017) (Vol. 107, hal. 55-58), 2017.

[8] D. P. Yanda, "Effect of Cooperative Learning Model Type Student Team Achievement Division ( STAD ) on Skill Understanding Poetry," Sixth Int. Conf. Lang. Arts (ICLA 2017), 2018.

[9] D. Arisanty, "Application Of Student Teams-Achievement Divisions ( Stad ) On Material Of Land Degradation And Impact on Humans," 1st Int. Conf. Soc. Sci. Educ. "Multicultural Transform. Educ. Soc. Sci. Wetl. Environ. (ICSSE 2017), 2018.

[10] E. W. Simamora, "The Effect of Student Team Achievement Division Cooperative Learning ( Stad Cl) in Teaching the Reading Comprehension.," 2nd Annu. Int. Semin. Transform. Educ. Educ. Leadersh. (AISTEEL 2017), 2017.

[11] S. Nina Yunita Ginting, "The Effectiveness on Mind Mapping Learning Model to Improve The Learning Achievements of Biology (Quasi Experimental Study at State Senior High School 1 of Binjai City North Sumatera Indonesia)," in Proceedings of the 2nd Annual International Seminar on Transformative Education and Educational Leadership (AISTEEL 2017), 2017.

[12] A. Putra, A. B. N. R., Sumarli, Poerwanto, E. E., \& Sholah, "Mind Mapping Learning Model to Increase Student Competency and Pattern Thoughts With Mixed Methods Research Approach," Proc. 1St Int. Conf. Vocat. Educ. Train. (Icovet 2017), 2017.

[13] M. G. Miranti and B. Y. Wilujeng, "Creative Thinking Skills Enhancement Using Mind Mapping," in Proceedings of the 1st International Conference on Social, Applied Science and Technology in Home Economics (ICONHOMECS 2017), 2018.

[14] M. Demitra and M. Sarjoko, "The Effect of Handep Cooperative Learning Model on Social Skill and Motivation to Learn Mathematics," in Proceedings of the 5th SEA-DR (South East Asia Development Research) International Conference 2017 (SEADRIC 2017), 2017. 